\title{
Abbreviations of Works by Jacques Derrida
}

"AANJ" “Above All, No Journalists!" Trans. Samuel Weber. In Religion and Media, ed. Hent de Vries and Samuel Weber, 56-93. Stanford, Calif:: Stanford University Press, 2001. (In Cahier de l'Herne: Derrida, ed. Marie-Louise Mallet and Ginette Michaud, 35-49. Paris: Éditions de l'Herne, 2004; rpt. as Surtout pas de journalistes! Paris: Éditions de L'Herne, 2005.)

AEL Adieu: To Emmanuel Levinas. Trans. Pascale-Anne Brault and Michael Naas. Stanford, Calif.: Stanford University Press, 1999. (Adieu à Emmanuel Lévinas. Paris: Éditions Galilée, 1997.)

AF Archive Fever. Trans. Eric Prenowitz. Chicago: University of Chicago Press, 1996. (Mal d'archive. Paris: Éditions Galilée, 1995.)

AL Acts of Literature. Ed. Derek Attridge. London: Routledge, 1992.

AP Aporias. Trans. Thomas Dutoit. Stanford, Calif.: Stanford University Press, 1993. (Apories. Paris: Éditions Galilée, 1996.)

AR Acts of Religion. Ed. Gil Anidjar. New York: Routledge, 2002.

ATT The Animal That Therefore I Am. Trans. David Wills. New York: Fordham University Press, 2008. (L'animal que donc je suis. Ed. Marie-Louise Mallet. Paris: Éditions Galilée, 2006.) 
BS 1 The Beast and the Sovereign. Vol. 1, Seminar of 2001-2002. Trans. Geoffrey Bennington. Chicago: University of Chicago Press, 2009. (La bête et le souverain. Vol. 1, 2001-2002. Ed. Michel Lisse, Marie-Louise Mallet, and Ginette Michaud. Paris: Éditions Galilée, 2008.)

BS 2 The Beast and the Sovereign. Vol. 2, Seminar of 2002-2003. Trans. Geoffrey Bennington. Chicago: University of Chicago Press, 2010. (La bête et le souverain. Vol. 2, 2002-2003. Ed. Michel Lisse, Marie-Louise Mallet, and Ginette Michaud. Paris: Éditions Galilée, 2009.)

"CF" "Le cinéma et ses fantômes." Interview with Antoine de Baecque and Thierry Jousse. Les cahiers du cinéma 556 (April 2001): 74-85.

CFU Chaque fois unique, la fin du monde. Ed. Pascale-Anne Brault and Michael Naas. Paris: Éditions Galilée, 2003. (For the English edition, see WM.)

"CHM" "Cogito and the History of Madness." Trans. Alan Bass. In Writing and Difference. Chicago: University of Chicago Press, 1978, 31-63. ("Cogito et historie de la folie." In L'écriture et la différence. Paris: Éditions du seuil, 1967, 51-97.)

"CS" Countersignature." Trans. Mairéad Hanrahan. Paragraph 27, no. 2 (2004): 7-42. (“Contresignature." In Poétiques de Jean Genet: La traversée des genres. Actes du Colloque Cerisyla-Salle 2000. Ed. Albert Dichy et Patrick Bougon, Paris: IMEC, 2004.)

D Demeure: Fiction and Testimony. Trans. Elizabeth Rottenberg. Stanford, Calif:: Stanford University Press, 2000.

"D" Différance." Trans. Alan Bass. In Margins of Philosophy (Chicago: University of Chicago Press, 1982), 1-27.

"EF" "Epochē and Faith: An Interview with Jacques Derrida." An interview with John D. Caputo, Kevin Hart, and Yvonne Sherwood. In Derrida and Religion: Other Testaments, ed. Yvonne Sherwood and Kevin Hart, 27-50. New York: Routledge, 2005.

ET Echographies of Television. With Bernard Stiegler. Trans. Jennifer Bajorek. Cambridge: Polity Press, 2002. (Échographies de la télévision: Entretiens filmés. Paris: Éditions Galilée/Institut National de l'Audiovisuel, 1996.)

"FK" "Faith and Knowledge: The Two Sources of 'Religion' at the Limits of Reason Alone." Trans. Samuel Weber. In Religion, ed. 
Jacques Derrida and Gianni Vattimo, 1-78. Stanford, Calif:: Stanford University Press, 1998. ("Foi et savoir." In $L a$ religion, ed. Jacques Derrida et Gianni Vattimo, 9-86. Paris: Éditions du Seuil, 1996.)

"FL" "Force of Law: The 'Mystical Foundation of Authority." Trans. Mary Quaintance. In AR, 230-298. (Force de loi. Paris: Éditions Galilée, 1994.)

"FOR" "Fors: The Anglish Words of Nicolas Abraham and Maria Torok." Trans. Barbara Johnson. Preface to The Wolf Man's Magic Word: A Cryptonymy, by Nicolas Abraham and Maria Torok. Trans. Nicholas Rand. Minneapolis: University of Minnesota, 1986, xi-xlviii. ("Fors," preface to Nicolas Abraham and Maria Torok, Le verbier de l'Homme aux loups. Paris: Aubier-Flammarion, 1976.)

FS For Strasbourg: Conversations of Friendship and Philosophy. Ed. and trans. Pascale-Anne Brault and Michael Naas. New York: Fordham University Press, 2014.

"G 1" “Geschlecht I: Sexual Difference, Ontological Difference." Trans. Ruben Bevezdivin and Elizabeth Rottenberg. PSY 2 7-26. ("Différence sexuelle, différence ontologique: [Geschlecht I], in Heidegger et la question: De l'esprit et autres essais. Paris: Flammarion, 1990, 145-172; first published in the Cahier de l'Herne devoted to Heidegger.)

"G 2" “Geschlecht II: Heidegger's Hand.” Trans. John P. Leavey, Jr. and Elizabeth Rottenberg. In PSY 2 27-62; first published in Deconstruction and Philosophy, ed. John Sallis. Chicago: University of Chicago Press, 1987, 161-196. ("La main de Heidegger: [Geschlecht II], in Heidegger et la question: De l'esprit et autres essais. Paris: Flammarion, 1990, 173-222.)

"G 4" "Heidegger's Ear: Philopolemology (Geschlecht IV)." Trans. John P. Leavey, Jr. In Reading Heidegger: Commemorations, ed. John Sallis, 163-218. Bloomington: Indiana University Press, 1993. ("L'oreille de Heidegger: Philopolémologie [Geschlecht IV].” In Politiques de l'amitié. Paris: Éditions Galilée, 1994, 343-419.)

IW Islam \& the West: A Conversation with Jacques Derrida. Mustapha Chérif. Trans. Teresa Lavender Fagan. Chicago: University of Chicago Press, 2008. ("L'Islam et l'Occident: Rencontre avec Jacques Derrida.” Mustapha Chérif. Paris: Odile Jacob, 2006.) 
“J” "Justices.” Trans. Peggy Kamuf. In Critical Inquiry 31, no. 3 (Spring 2005): 689-721.

"LJF" "Letter to a Japanese Friend." Trans. David Wood and Andrew Benjamin. In PSY 2, 1-6; first published in Derrida \& Différance. Warwick: Parousia Press, 1985, 1-8.

LLF Learning to Live Finally: The Last Interview. Trans. Pascale-Anne Brault and Michael Naas. Hoboken, N.J.: Melville House, 2007. (Apprendre à vivre enfin: Entretien avec Jean Birnbaum. Paris: Éditions Galilée/Le Monde, 2005.)

"LO” "Living On: Border Lines." Trans. James Hulbert. In Deconstruction and Criticism. New York: Seabury Press/ Continuum Press, 1979, 62-142. (“Survivre." In PAR, 117-218.)

MB Memoirs of the Blind: The Self-Portrait and Other Ruins. Trans. Pascale-Anne Brault and Michael Naas. Chicago: University of Chicago Press, 1993. (Mémoires d'aveugle: L'autoportrait et autres ruines. Paris: Éditions de la Réunion des musées nationaux, 1990.)

N Negotiations: Interventions and Interviews, 1971-2001. Ed. Elizabeth Rottenberg. Stanford, Calif.: Stanford University Press, 2002.

"NA" "No Apocalypse, Not Now: Full Speed Ahead, Seven Missiles, Seven Missives." Trans. Catherine Porter and Philip Lewis. In PSY 1 387-409. ("No apocalypse, not now (à toute vitesse, sept missiles, sept missives," in Psyché 1 395-418.)

OG Of Grammatology. Trans. with a preface by Gayatri Chakravorty Spivak. Baltimore: Johns Hopkins University Press, 1976. (De la grammatologie. Paris: Éditions de Minuit, 1967.)

OS Of Spirit: Heidegger and the Question. Trans. Geoffrey Bennington and Rachel Bowlby. Chicago: University of Chicago Press, 1991. (De l'esprit: Heidegger et la question. Paris: Éditions Galilée, 1987.)

P Points... Interviews, 1974-1994. Ed. Elisabeth Weber. Trans. Peggy Kamuf and others. Stanford, Calif.: Stanford University Press, 1995. (Points de suspension: Entretiens. Edited and presented by Elisabeth Weber. Paris: Éditions Galilée, 1992.)

PAR Parages. Ed. John P. Leavey Jr. Trans. Tom Conley, James Hulbert, John P. Leavey, and Avital Ronell. Stanford, Calif.: 
Stanford University Press, 2010. (Parages. Revised and augmented. Paris: Éditions Galilée, 2003.)

PC The Post Card: From Socrates to Freud and Beyond. Trans. Alan Bass. Chicago: University of Chicago Press, 1987. (La carte postale: de Socrate à Freud et au-delà. Paris: Flammarion, 1980.)

PM Paper Machine. Trans. Rachel Bowlby. Stanford, Calif:: Stanford University Press, 2005. (Papier Machine: Le ruban de machine à écrire et autres réponses. Paris: Éditions Galilée, 2001.)

PSY 1 Psyche 1: Inventions of the Other. Ed. Peggy Kamuf and Elizabeth Rottenberg. Stanford, Calif.: Stanford University Press, 2007. (Psyché: Inventions de l'autre. Vol. 1. Paris: Éditions Galilée, 1987, 1998.)

PSY 2 Psyche 2: Inventions of the Other. Ed. Peggy Kamuf and Elizabeth Rottenberg. Stanford, Calif.: Stanford University Press, 2008. (Psyché: Inventions de l'autre. Vol. 2. Paris: Éditions Galilée, 1987, 2003.)

$R \quad$ Rogues: Two Essays on Reason. Trans. Pascale-Anne Brault and Michael Naas. Stanford, Calif:: Stanford University Press, 2005. (Voyous. Paris: Éditions Galilée, 2003.)

SM Specters of Marx: The State of the Debt, the Work of Mourning, and the New International. Trans. Peggy Kamuf. New York: Routledge, 1994. (Spectres de Marx. Éditions Galilée, 1993.)

SQ Sovereignties in Question: The Poetics of Paul Celan. Ed. Thomas Dutoit and Outi Pasanen. New York: Fordham University Press, 2005.

“TA" "Trace et archive, image et art. Dialogue.” Remarks offered on 25 June 2002; available at www.ina.fr/inatheque/activites /college/pdf/2002.

VM "Violence and Metaphysics: An Essay on the Thought of Emmanuel Levinas." Trans. Alan Bass. In Writing and Difference. Chicago: University of Chicago Press, 1978, 79-153. ("Violence et métaphysique: Essai sur la pensée d' Emmanuel Levinas." In L'écviture et la différence. Paris: Éditions du Seuil, 1967, 117-228).

WA Without Alibi. Ed. Peggy Kamuf. Stanford, Calif.: Stanford University Press, 2002.

WM The Work of Mourning. Ed. Pascale-Anne Brault and Michael Naas. Chicago: University of Chicago Press, 2001. (For the French version, see $C F U$.) 
This page intentionally left blank 


\section{Acknowledgments}

Early versions of several chapters of this book have been presented at conferences or given as lectures, and some have been published in shortened versions elsewhere. This work has benefited enormously from the questions and conversations that followed each lecture or conference presentation and from the careful attention of copyeditors and editors. Those who read or heard those earlier versions will recognize here the traces of their questions, comments, and suggestions. I would like to thank these friends and colleagues for their hospitality and kind attention: Gianfranco Dalmasso at the Università di Bergamo, Kevin Newmark at Boston College, Ted Jennings, Virgil Brower, Tony Hoshaw, and Kuni Sakai at Chicago Theological Seminary, Keith Peterson at Colby College, Joshua Ben David Nichols and Amy Swiffen at Concordia University, Pablo Lazo Briones at Universidad Iberoamericana in Mexico City, Marc Crépon at the École Normale Supérieure in Paris, David Jones at Kennesaw State University, Carmine DiMartino at the Università di Milano, Andrew Benjamin at Monash University, Ben Vedder and Gert-Jan van der Heiden at Radboud University in Nijmegen, Patrick Gamez and Tony Mills at the University of Notre Dame, Penelope Deutscher, Michael Loriaux, and Nasrin Qader at Northwestern University, Ted Toadvine, Alejandro Vallega, Daniela Vallega-Neu, and Peter Warnek at the University of Oregon, Leonard Lawlor, Jennifer Mensch, and Dennis Schmidt at Penn State University, Kas Saghafi (and the sponsors of the 2011 Spindel Conference) at the University of Memphis, Andrew Lazella, Crina Gschwandtner, and 
Sharon Meagher at the University of Scranton, Allison Tyndall Locke, Laura James, and Eduardo Mendieta at Stony Brook University, Nicholas Royle at the University of Sussex (along with my other co-editors of the Oxford Literary Review, who joined me at Sussex in a series of conferences on Derrida's seminars: Geoffrey Bennington, Timothy Clark, Peggy Kamuf, and Sarah Wood), and Shannon Mussett and Michael Shaw at Utah Valley University. I am particularly grateful to Jeffrey Nealon at Penn State University and Kelly Oliver at Vanderbilt University, who both offered me many excellent suggestions and much-needed encouragement on an earlier draft of this work. I would like to offer a special word of thanks to Jeffrey McCurry and John Sallis for their generous invitation to present an early version of the final chapter of the book as the Andre Schuwer Memorial Lecture, sponsored by the Simon Silverman Phenomenology Center at Duquesne University, at the 2011 meeting of the Society for Phenomenology and Existential Philosophy. This invitation was for me all the more precious insofar as I had the good fortune of meeting André Schuwer on several occasions and so was able to experience firsthand his kindness, generosity, and good humor, as well as his formidable but always self-effacing intelligence.

Chapters 1 and 7 were originally published in Research in Phenomenology, the first in volume 40, no. 2 (2010): 219-242 and the second in volume 44 , no. 1 (2014): 1-27. I am grateful to the journal's editor, John Sallis, for allowing me to republish revised versions of these essays. An early version of Chapter 2 was published in The Ends of History: Questioning the Stakes of Historical Reason, ed. Joshua Nichols and Amy Swiffen (New York: Routledge, 2013), 161-178. A version of Chapter 3 first appeared in Societies, 2 (2012): 317-331. A revised version of Chapter 4 appeared in Thinking Plurality, ed. Gert-Jan van der Heiden (Leiden: Brill, 2014). An abbreviated version of Chapter 5 was published in L'a-venire di Derrida, ed. Gianfranco Dalmasso, Carmine DiMartino, and Caterina Resta (2014). Finally, a shorter version of Chapter 6 appeared in a special issue of SubStance devoted to Derrida's The Beast and the Sovereign (2014).

I would like to thank here my friends and colleagues in the Derrida Seminar Translation Project, who have taught me so much over the last five years about the seminars at our annual week-long meeting at IMEC (Institut Mémoires de l'édition contemporaine) in Normandy, France: Geoffrey Bennington (Emory University), Peggy Kamuf (University of Southern California), Kir Kuiken (SUNY at Albany), Kas Saghafi (University of Memphis), David Wills (Brown University), and, at DePaul, Elizabeth Rottenberg and Pascale-Anne Brault. I am also very grateful to my students and other colleagues at DePaul, especially Will McNeill, 
whose graduate seminar in autumn 2011 on Heidegger's Fundamental Concepts of Metaphysics was truly invaluable as I myself was teaching a seminar on Derrida's The Beast and the Sovereign.

Finally, I would like to express my deep gratitude to David Farrell Krell, for his unparalleled knowledge of Heidegger and Derrida, to be sure, but especially for so many years of conversation and friendship. The discerning reader will be able to trace the influence of his work, his generosity, and his friendship on just about every page of this book. 
This page intentionally left blank 